\title{
POEMAS
}

\section{George Bacovia}

\author{
Traducción de Aleqs Garrigóz
}

\section{TARDE SOMBRÍA}

Bárbaramente esa mujer cantaba en el café desierto, aquella tarde. Bárbaro y lleno de dolor era el canto y había tanto ruido alrededor: el monstruoso estruendo de los címbalos.

Bárbaramente esa mujer cantaba.

Bárbaramente esa mujer cantaba...

Y allí estábamos en tal penumbra, entre nubes espesas de humo de cigarro reflexionando en mundos que no existen... Con tremendo esplendor satánico bárbaramente esa mujer cantaba.

Bárbaramente esa mujer cantaba, y había tanto ruido alrededor...

Desganados por irnos a casa, de bruces sobre la mesa, llorábamos; mientras en el café desierto bárbaramente esa mujer cantaba...

\section{CUADRO INVERNAL}

Nieva terriblemente en el campo cerca del matadero; y la sangre tibia escurre hacia el desagüe.

La nieve está espesa de sangre animal.

Está nevando sobre una pista de hielo sin nadie.

La sangre congelada alumbra sobre lo blanco;

los cuervos pasean chupando la sangre.

Es tarde ya ... Hacia los cielos emigran los cuervos.

En el campo, cerca del matadero, se ha vuelto noche.
Sigue nevando en un cielo silencioso; $\mathrm{y}$ ahora que las lúgubres ventanas se encienden, los lobos de ojos chispeantes se van aproximando.

-Soy yo, amor, frente a tu puerta congelada.

\section{A C USTRE}

Tantas noches he escuchado la lluvia; he escuchado la materia que llora... Estoy solo. Lentamente voy ahogándome en esta morada lacustre.

Duermo sobre tablones mojados, una ola me golpeará la espalda. Despierto estremecido: ¿han retirado el puente a la orilla?

Una era vacía se ha extendido. Me encuentro a mí mismo igual que siempre. Siento cómo por la incesante lluvia los pesados pilares se colapsan.

Tantas noches he escuchado la lluvia, siempre esperando, esperando... Estoy solo... Lentamente voy ahogándome en esta morada lacustre.

\section{NEUROSIS}

Mi amada toca el piano, afuera cae la nieve sobre las ruinas. El pueblo está oscurecido y nieva sobre el cementerio. 
Mi amada toca una marcha fúnebre.

Yo estoy perplejo y pregunto -iPor qué?, ¿por qué está tocando una marcha fúnebre...? Sigue nevando en el cementerio.

Ella llora. Se ha derrumbado sobre el teclado y gime, febril, duramente...

La música del piano muere en una discordia.

Sigue nevando en el cementerio.

Tiemblo, extiendo sus cabellos y sobre sus hombros lloro yo también... Afuera el pueblo está desierto.

Y sigue nevando en el cementerio...

\section{F R Í O}

Cerca de una valla rota

el viento me golpea con hojas mojadas.

Estoy cada vez más feo, más acabado.

El frío va empañando los vidrios.

Sobre la calle que se inclina en descenso hace un otoño parecido a un poema viejo. Las faldas de las mujeres se levantan por el viento; nunca podré hacer pareja con alguna de ellas.

El otoño desgarra carteles y flores.

Y es cada vez más triste, lejos, en los barrancos, encender el fuego varias veces al día. Ah, más triste todavía, lejos, en los barrancos... Hojuelas de nieve revolotean....

\section{EN EL PARQUE}

Hoy, el parque devastado, enfermo y roído por el cáncer social y la corrupción, se ha manchado de rojo rápido.

Ambulancias de hospital pasan en sucesión.

Ella solía reír.

Alas de alegría revoloteaban a su alrededor. Esencia, polen e histeria. Luego vino al parque.

Hoy en las estatuas blancas femeninas gotas de sangre van escurriendo. El parque vacío. El mármol de formas delicadas de la escena de violación fue testigo...

\section{P A L I D E Z}

Soy el solitario de las cuadras desiertas con lámparas deprimentes que expiran luz pálida. Cuando la campana suena en la negrura de la noche... soy el solitario de las cuadras desiertas.

La risa vil es mi camarada ... y las sombras que asustan a perros perdidos en la avenida. Bajo las deprimentes lámparas que expiran luz pálida, viles risas son mis camaradas... y las sombras.

Soy el solitario de las cuadras desiertas con juegos de sombra que producen locura. Palideciendo en silencio y en parálisis... ¡Soy el solitario de las vías desiertas!

\section{ME L A N C O L Í A}

¡Qué gritos, qué gemidos de otoño; y cómo salvajemente el campo está zumbando! Un cuerno resuena huecamente y lamentos cada vez más tristes hacen aparición.

Escucha atentamente, amada, no te alarmes, no tiembles de miedo. Escucha cómo la cruel naturaleza nos llama, desde adentro...

\section{I C I E M B R E}

Ve cómo nieva en diciembre.

Mira la nieve en la ventana, mi amada.

Pide que traigan más leña, para poder el fuego escuchar rugir.

Empuja el sillón cerca a la estufa, que en la chimenea lo hemos de oír. Debo aprender la sinfonía de la tormenta o de mis días -es lo mismo.

Pide también que traigan el té y ven más cerca, más cerca, por favor.

Léeme algo sobre los polos.

Deja que la nieve nos sepulte... Nos sepulte.

Qué tibieza aquí en tu casa; para mí es totalmente sagrada. Mira cómo nieva en diciembre. No rías. Sigue tú leyendo... 
Es de día ¡y qué oscuridad hay!

Necesitamos una lámpara... ¿La traerás?

Mira, la nieve es ya tan alta como la cerca,

el cerrojo de la puerta se ha atascado por la escarcha.

Hoy no iré a ningún lado:

el pórtico y el patio se han inundado de nieve.

Mira cómo nieva en diciembre.

No rías. Sigue tú leyendo...

\section{E S C E N A}

Árboles blancos, árboles negros, desnudos en el parque solitario: una escena de luto, desolada...

Árboles blancos, árboles negros.

Otra vez los dolidos van al parque a llorar...

Con alas blancas, alas negras, vaga un ave con voz angustiada a través del parque milenario... Con plumas blancas, plumas negras.

Fantasmas aparecen en el parque solitario...

Y hojas blancas, hojas negras; árboles negros, árboles negros; y plumas blancas, plumas negras. Una escena de luto, desolada...

Una gradual nevada el parque solitario... LPyH 